\title{
PENINGKATAN HASIL BELAJAR SISWA PADA MATA PELAJARAN BAHASA INGGRIS MELALUI METODE EKSPERIMEN SAINS SEDERHANA
}

\author{
SRI MULYANI \\ MTs Negeri 3 Kayong Utara \\ e-mail: myanihasan@gmail.com
}

\begin{abstract}
ABSTRAK
Penelitian ini bertujuan untuk memperoleh informasi peningkatan hasil belajar siswa pada materi teks Prosedur kelas IX di MTs Negeri 3 Kayong Utara setelah menerapkan metode pembelajaran Eksperimen sains sederhana yang merupakan pengembangan dari model pembelajaran Demonstrasi pada pembelajaran bahasa Inggris. Metode Eksperimen sains sederhana ini diterapkan selain untuk meningkatkan hasil belajar siswa juga dapat meningkatkan keterampilan berbicara dan mengintegrasikan antara pembelajaran bahasa Inggris dengan sains. Instrumen dalam penelitian ini adalah tes hasil belajar berbentuk : (1) Tes, (2) Observasi, (3) angket. Untuk mengetahui peningkatan hasil belajar dilihat dari perbandingan hasil tes antar siklus. Penerapan metode Eksperimen sains sederhana dapat meningkatkan hasil belajar siswa pada materi Procedure text atau teks Prosedur. Hasil pelaksanaan siklus I dengan menerapkan metode ceramah diperoleh tingkat ketuntasan 44,5\% sedangkan pelaksanaan siklus II dengan menerapkan metode Eksperimen sains sederhana diperoleh ketuntasan klasikal 88,9\%. Aktifitas pembelajaran dengan menggunakan metode Eksperimen sains sederhana berhasil dalam meningkatkan hasil belajar siswa pada materi teks Prosedur. Jenis metode penelitian yang digunakan adalah Kuantitatif.
\end{abstract}

Kata Kunci: Hasil belajar, Model pembelajaran Demonstrasi, Metode Eksperimen Sains Sederhana

\section{PENDAHULUAN}

Salah satu tuntutan dari Kompetensi Dasar (KD) dan Indikator Pencapaian Kompetensi (IPK) dalam mata pelajaran Bahasa Inggris adalah penggunaan ragam bahasa lisan secara akurat dan lancar. Hal ini sangat beralasan karena karakteristik mata pelajaran Bahasa Inggris menekankan tidak hanya pada aspek pengetahuan semata namun juga pada 4 (empat) keterampilan yaitu mendengar, berbicara, membaca dan menulis. Salah satu bentuk keterampilan yaitu berbicara atau speaking skill perlu mendapat perhatian secara khusus tidak hanya oleh para guru dan siswa namun juga pihak-pihak yang berwenang di lingkungan pendidikan. Hal ini disebabkan masih rendahnya kualitas berbahasa Inggris di Indonesia karena Bahasa Inggris bukan dijadikan sebagai bahasa kedua atau English as Second Language (ESL) seperti di negara-negara lainnya. Kecakapan bahasa Inggris di Indonesia ternyata masih rendah, berada di peringkat 74 , dari 100 negara berdasarkan EF English Proficiency Index edisi tahun 2020, atau indeks kecakapan Bahasa Inggris yang dikeluarkan oleh EF Education First, perusahaan pendidikan international yang fokus pada bahasa akedemisi, pertukaran budaya, dan perjalanan pendidikan. Dari fakta yang diperoleh tersebut sudah seyogyanya para guru bidang studi bahasa Inggris lebih aktif dan kreatif dalam penyampaian pembelajaran yang membuat kelas menjadi hidup dan interaktif, meningkatkan minat belajar yang pada akhirnya meningkatkan hasil belajar itu sendiri. Keterampilan berbahasa Inggris yang diperoleh para siswa di bangku sekolah akan sangat bermanfaat bagi mereka ketika berada di lingkungan kerja nantinya.

Pada setiap aktifitas pembelajaran dalam bidang apapun, hasil belajar merupakan hal terpenting yang akan di analisa, karena hasil belajar bisa menjadi salah satu tolok ukur apakah pembelajaran yang sudah dilaksanakan baik oleh guru maupun siswa sudah mencapai target yang direncanakan atau belum.

Metode pembelajaran yang dipilih dan diterapkan oleh para guru akan sangat menentukan hasil pembelajaran di dalam kelas. Metode pembelajaran yang dipilih lebih 
menekankan pada keaktifan siswa sehingga pembelajaran tersebut akan lebih bermakna atau meaningful learning. Salah satu model pembelajaran yang dianggap representatif dalam mengakomodir keaktifan siswa dalam pembelajaran adalah model Demonstrasi. Model pembelajaran ini digunakan karena sesuai dengan materi yang memerlukan peragaan media atau eksperimen. Modelpembelajaran Demonstrasi adalah peragaan atau pertunjukan tentang cara melakukan atau mengerjakan sesuatu. Model demonstrasi merupakan model yang paling sederhana dibandingkan dengan model mengajar lainnya (Hardini 2012:27). Dengan model demonstrasi mempunyai kelebihan terjadinya verbalisme dapat dihindari sebab peserta didik disuruh langsung memperhatikan bahan pelajaran yang dijelaskan, proses pembelajaran akan lebih menarik serta pengajaran menjadi lebih jelas dan konkret serta bisa merangsang peserta didik mengamati dan menyesuaikan antara teori dengan kenyataan.

Langkah-langkah dalam model pembelajaran ini adalah: informasi kompetensi, sajian gambaran umum materi bahan ajar, membagi tugas pembahasan materi untuk tiap kelompok, menunjuk siswa atau kelompok untuk mendemonstrasikan bagiannya, dikusi kelas, penyimpulan dan evaluasi, refleksi.

Materi yang diajarkan adalah teks Prosedur di kelas IX dimana di dalamnya dipelajari dan dibahas tentang bagaimana membuat/ menggunakan sesuatu. Dalam penelitian ini, dilakukan pengintegrasian dengan bidang sains dimana siswa melakukan praktik eksperimen atau percobaan sains sederhana. Ada sedikit perbedaan ketika melakukan teks prosedur dalam bentuk praktik sains yaitu adanya kesimpulan atau conclusión dalam setiap teks nya. Maka metode pembelajaran eksperimental atau percobaan sederhana dianggap relevan dalam menciptakan suasana yang menarik dan menyenangkan dalam pembelajaran di dalam kelas. Melalui metode eksperimen dapat memberikan kesempatan pada siswa untuk terlibat secara langsung dalam sebuah proses terjadinya suatu permasalahan. Metode eksperimen membuat siswa lebih yakin atas hasil yang mereka dapat karena mereka terlibat dan mengalami secara langsung dalam sebuah eksperimen. Menurut Roestiyah (2012:82) ada beberapamanfaat metode eksperimen sains bagi anak yaitu : 1) Dengan eksperimen anak terlatih untuk menggunakan metode ilmiah dalam menghadapi segala masalah, sehingga tidak mudah percaya pada sesuatu yang belum pasti kebenarannya dan tidak mudah percaya pula kata orang sebelum ia membuktikan kebenarannya. 2) Mereka lebih aktif berfikir dan berbuat hal yang memang ditargetkan dalam kegiatan mengajar belajar yang modern, dimana anak lebih banyak aktif belajar sendiri dengan bimbingan guru. 3) Anak dalam melaksanakan proses eksperimen di samping memperoleh ilmu pengetahuan juga menemukan pengalaman praktis serta keterampilan dalam menggunakan alat-alat percobaan. Hamid (2011:212) mengungkapkan bahwa "Metode eksperimen adalah metode pemberian kesempatan kepada anak, baik secara perorangan atau secara kelompok untuk dilatih melakukan suatu proses atau percobaan, di mana anak bisa sepenuhnya terlibat dalam merencanakan dan melakukan eksperimen, menemukan fakta, mengumpulkan data, mengendalikan variabel, dan memecahkan masalah yang dihadapinya secara nyata". Selanjutnya Menurut Sri Anitah W, dkk (1998:157) "Metode eksperimen merupakan metode mengajar yang dalam penyajian atau pembahasan materinya melalui percobaan atau mencobakan sesuatu serta mengamati secara proses". Menurut Nasrudin (2007: 28), "Sains adalah suatu pengetahuan teoritis yang diperoleh atau disusun dengan cara yang khas, yaitu melakukan pengamatan, percobaan, penyimpulan, penyusunan teori, dan demikian seterusnya kait-mengkait antara cara yang satu dengan cara yang lain". Anitah (2007:5.29), mengemukakan prosedur penggunaan metode eksperimen adalah sebagai berikut. 1) Mempersiapkan alat bantu (alat eksperimen). 2) Petunjuk dan informasi tentang tugas-tugas yang harus dilaksanakan dalam eksperimen. 3) Pelaksanaan eksperimen dengan menggunakan lembaran kerja/pedoman eksperimen yang disusun secara sistematis sehingga siswa dalam pelaksanaannya tidak banyak mendapat kesulitan dan membuat laporan. 4) Penguatan perolehan temuan-temuan eksperimen dilakukan dengan diskusi, tanya jawab, dan/atau tugas. 5) Kesimpulan. 
Anitah, dkk (2007:5.28) mengemukakan beberapa kelebihan dan kekurangan dalam implementasi metode eksperimen, diantaranya adalah sebagai berikut; a. Kelebihan metode eksperimen: 1) Membangkitkan rasa ingin tahu siswa. 2) Membangkitkan sikap ilmiah siswa. 3) Membuat pembelajaran bersifat aktual. 4) Membina kebiasaan belajar kelompok maupun individu. b. Kekurangan metode eksperimen: 1) Memerlukan alat dan biaya. 2) Memerlukan waktu relatif lama. 3) Sangat sedikit sekolah yang memiliki fasilitas eksperimen. 4) Guru dan siswa banyak yang belum terbiasa melakukan eksperimen.

Menurut Sagala (2005:221), ada beberapa cara untuk mengatasi kelemahan-kelemahan dari metode eksperimen: 1) Hendaknya guru menerangkan sejelas-jelasnya tentang hasil yang ingin dicapai sehingga ia mengetahui pertanyaan-pertanyaan yang perlu dijawab dengan eksperimen. 2) Hendaknya guru membicarakan bersama-sama dengan anak tentang langkah yang dianggap baik untuk memecahkan masalah dalam eksperimen, serta bahan-bahan yang diperlukan, variabel yang perlu dikontrol dan hal-hal yang perlu dicatat. 3) Bila perlu, guru menolong anak untuk memperoleh bahan-bahan yang diperlukan. 4) Guru perlu merangsang agar setelah eksperimen berakhir, ia membanding bandingkan hasilnya dengan eksperimen orang lain dan mendiskusikannya bila ada perbedaan-perbedaan atau kekeliruan

\section{METODE PENELITIAN}

Metode penelitian yang digunakan adalah Kuantitatif, dimana dalam metode ini meneliti populasi atau sampel. Data dikumpulkan dengan menggunakan instrumen atau alat ukur, kemudian dianalisis dengan statistik atau secara kuantitatif. Jenis penelitian ini adalah Penelitian Tindakan Kelas (Classroom Action Research) dimana sasaran atau subjek penelitiannya adalah siswa kelas IX Madrasah Tsanawiyah Negeri 3 Kayong Utara Tahun Pelajaran 2019-2020 yang berjumlah 18 orang. Objek penelitian ini adalah penerapan metode eksperimen sains sederhana pada materi teks prosedur mata pelajaran Bahasa Inggris. Penelitian ini dilakukan dengan tujuan selain untuk memperbaiki hasil belajar siswa di dalam kelas juga untuk mengintegrasikan materi sains dalam mata pelajaran Bahasa Inggris . Dalam penelitian ini digunakan tiga jenis alat pengumpul data, yaitu tes, observasi dan angket.

\section{HASIL DAN PEMBAHASAN}

\section{A. Hasil Penelitian}

Sebelum dilaksanakan Penelitian Tindakan Kelas (PTK), motivasi siswa dalam pembelajaran masih rendah dimana hal ini dapat diketahui melalui observasi yang dilakukan terhadap aktifitas siswa ketika proses pembelajaran berlangsung, siswa yang berperan secara aktif dalam proses pembelajaran baik dalam bentuk interaksi antar siswa maupun siswa dengan pengajar, ternyata dari seluruh siswa kelas IX yang berjumlah 18 orang hanya 5 orang atau $43 \%$ yang aktif sedangkan 13 orang siswa atau $57 \%$ kurang aktif. Perolehan hasil belajar masih rendah dengan prosentase ketuntasan hanya $44,5 \%$ atau ratarata 62,5. Setelah dilakukan tindakan siklus I, persentase keaktifan siswa adalah 62,5\%, dan setelah dilakukan tindakan pada siklus II keaktifan meningkat menjadi 79,7\% dengan prosentase ketuntasan sebesar 88,9\%. Penelitian yang dilakukan dalam dua siklus ini, siklus I dan siklus II dilaksanakan dari bulan Agustus hingga bulan September dibantu oleh seorang rekan guru sejawat yang bertindak sebagai observer dan teman berdiskusi pada tahap refleksi.

Adapun deskripsi hasil penelitian dapat diuraikan dalam tahapan siklus-siklus pembelajaran berikut ini;

\section{B. Siklus I}

Dalam pelaksanaan siklus I, maka peneliti menyusun kegiatan-kegiatan sebagai berikut;

1) Tahap Perencanaan.

Dalam tahap ini peneliti melakukan (1) analisis kurikulum untuk mengetahui kompetensi dasar yang akan disampaikan, (2) membuat rencana pembelajaran dengan mengacu pada 
tindakan dalam penelitian, (3) membuat lembar kerja siswa, lembar pengamatan, lembar evaluasi.

2) Tahap Pelaksanaan.

Peneliti menerapkan tindakan mengacu pada skenario model pembelajaran demonstrasi dengan metode eksperimen sains sederhana. Langkah-langkah yang dilakukan antara lain; (1) memilih tema yang menarik untuk disampaikan, (2) memperkenalkan teks prosedur dan menjelaskan poin-poin pokok.

3) Melakukan evaluasi hasil belajar siswa

4) Melakukan pegolahan hasil belajar siswa

5) Melakukan refleksi dan perencanaan ulang

Dari hasil belajar siswa setelah diberikan tindakan I dapat dilihat pada table berikut ;

\begin{tabular}{clc}
\begin{tabular}{c} 
Tabel 1. Distribusi Nilai Hasil Belajar Siswa Pada Siklus I \\
\hline No
\end{tabular} & \multicolumn{1}{c}{ Uraian } & Hasil Siklus I \\
\hline 1 & Nilai tertinggi & 87 \\
2 & Nilai terendah & 50 \\
3 & Nilai rata rata hasil tes & 62,5 \\
4 & Jumlah siswa yang tuntas belajar & 8 \\
5 & Jumlah siswa yang tidak tuntas belajar & 10 \\
6 & Persentase ketuntasan belajar & $44,5 \%$ \\
\hline
\end{tabular}

Dapat dideskripsikan bahwa dari 18 siswa, 8 orang talah mencapai ketuntasan belajar sedangkan 10 orang belum mencapai tingkat ketuntasan belajar. Tingkat ketuntasan klasikal yang diperoleh yaitu 44,5\% atau rata-rata 62,5, belum mencukupi syarat ketuntasan klasikal (75\%). Dari tes tersebut juga dapat diperoleh nilai terendah adalah 50 dan nilai tertinggi adalah 87 dengan rata-rata nilai adalah 62,5.

Untuk mengetahui kesulitan yang dialami siswa dalam melakukan praktik eksperimen sains maka peneliti menyebarkan angket kepada siswa siswa yang dikenakan tindakan I. Berdasarkan hasil angket dapat disimpulkan; (1) Siswa mengalami kendala dalam menentukan langkah-langkah dalam teks prosedur, (2) Siswa merasa grogi ketika berada di depan kelas, (3) Praktik eksperimen sains sederhana dianggap lebih rumit dibandingkan dengan praktik membuat sesuatu. (4) Siswa kurang memahami makna pertanyaan karena keterbatasan kosa kata dalam teks prosedur seperti jenis kata imperative,conjunction (5) Siswa kurang teliti dalam mengerjakan soal.

Observasi juga dilakukan mulai dari awal pelaksanaan tindakan hingga akhir, dimana pengamat atau observer mengamati pembelajaran yang menerapkan metode eksperimen sains sederhana sebagai salah satu upaya peningkatan hasil belajar siswa dalam materi teks Procedure.

Pada awal pelaksanaan tindakan siklus I belum sesuai dengan rencana dan masih terdapat beberapa kekurangan dalam pelaksanaan kegiatan belajar mengajar terutama dalam penggunaan metode eksperimen sains sederhana seperti yang digambarkan dalam refleksi antara lain;

1) Sebagian siswa belum terbiasa melakukan praktik di depan kelas khususnya melakukan ekperimen sains

2) Suasana kelas kurang rileks karena adanya kehadiran pengamat di dalam kelas

3) Siswa menemukan kendala dalam pengucapan atau lafal .

4) Siswa masih ada yang belum mampu dalam menggunakan ragam bahasa lisan secara akurat dan lancar.

Untuk menindak lanjuti hasil refleksi tersebut maka dilakukan upaya sebagai berikut;

1) Guru memberikan motivasi kepada siswa yang mengalami kesulitan

2) Guru secara intensif memberikan bimbingan kepada siswa yang mengalami kesulitan 
3) Guru memberikan arahan supaya siswa lebih memahami dan mensinkronkan antara teks yang disampaikan secara lisan dengan gerakan siswa melakukan eksperimen.

4) Membantu memahamkan siswa tentang langkah-langkah dalam teks prosedur melalui metode eksperimen sains sederhana.

5) Memberikan pengakuan atau penghargaan (reward) kepada siswa.

Dari hasil tes yang dilakukan pada siklus I, diperoleh 8 orang $(44,5 \%)$ siswa mencapai ketuntasan belajar dan 10 orang $(55,5 \%)$ belum mencapai tingkat ketuntasan belajar. Hal ini menggambarkan bahwa upaya guru dengan penerapan metode pembelajaran ekperimen sains sederhana belum sepenuhnya dipahami oleh siswa. Praktik Eksperimen sains yang dilakukan masih bersifat text book atau lebih banyak membaca teks. Padahal yang diharapkan pada penerapan metode ini adalah kemampuan siswa dalam mensingkronkan setiap langkah langkah ekperimen dengan instruksi verbal yang diucapkan berdasarkan pemahaman siswa. Selain itu beberapa siswa merasa kurang percaya diri pada saat melakukan praktik di depan kelas dan merasa grogi sehingga mengganggu kelancaran pelaksanaan eksperimen, beberapa siswa juga malu dan tidak berani bertanya kepada guru untuk mengulangi materi ataupun penjelasan guru yang belum dipahami. Karena banyak ditemukan kekurangan-kekurangan selama siklus I maka perlu dilakukan perbaikan tindakan di siklus II.

\section{Siklus II}

Kegiatan observasi tetap dilakukan oleh guru yang bertindak sebagai observer. Pengamatan dilakukan selama peneliti mengajar di dalam kelas melalui pemberian tugas dan latihan sebagai salah satu upaya meningkatkan hasil belajar siswa pada materi teks Prosedur. Kegiatan dalam siklus II tertuang dalam alur berikut;

1) Tahap Perencanaan.

Perencanaan siklus kedua berdasarkan replanning siklus pertama Dalam tahap ini peneliti melakukan (1) Memberikan motivasi supaya siswa lebih aktif dalam pembelajaran (2) lebih intensif memberi bimbingan kepada siswa yang mengalami kesulitan, (3) memberikan pengakuan atau penghargaan, (4) membuat perangkat pembelajaran menggunakan model pembelajran demonstrasi dengan metode eksperimen sains sederhana yang lebih mudah difahami oleh siswa.

2) Tahap Pelaksanaan.

Suasana pembelajaran sudah mengarah kepada pembelajaran dengan metode eksperimen. Tugas yang diberikan guru kepada siswa dengan menggunakan lembar kerja akademik dikerjakan dengan baik, siswa sudah termotivasi untuk bertanya dan menanggapi presentasi dari guru

3) Melakukan pengamatan

4) Melakukan refleksi

Dari hasil observasi yang dilakukan selama siklus II pada kegiatan penelitian diperoleh data bahwa kemampuan siswa dalam memahami pelajaran mengalami kenaikan. Setelah diadakan penelitian pada siklus I persentase keaktifan siswa adalah 62,5\%, setelah diadakan tindakan siklus II meningkat menjadi 79,7\%.

Dari hasil belajar siswa setelah diberikan tindakan I dapat dilihat pada table berikut ;

\begin{tabular}{clc}
\begin{tabular}{c} 
Tabel 2. \\
\hline No
\end{tabular} & \multicolumn{1}{c}{ Uristribusi Nilai Hasil Belajar Siswa Pada Siklus II } \\
\hline 1 & Nilai tertinggi & Hasil Siklus I \\
2 & Nilai terendah & 100 \\
3 & Nilai rata rata hasil tes & 60 \\
4 & Jumlah siswa yang tuntas belajar & 88,9 \\
5 & Jumlah siswa yang tidak tuntas belajar & 16 \\
6 & Persentase ketuntasan belajar & 2 \\
\hline
\end{tabular}


Dari tabel hasil tes belajar dapat dideskripsikan bahwa dari 18 siswa, 16 orang telah mencapai ketuntasan belajar sedangkan 2 orang belum mencapai tingkat ketuntasan belajar. Tingkat ketuntasan klasikal yang diperoleh yaitu 88,9 \% atau rata-rata 77,7 , sudah mencukupi syarat ketuntasan klasikal (75\%). Dari tes tersebut juga dapat diperoleh nilai terendah adalah 60 dan nilai tertinggi adalah 100 .

Adapun dari hasil refleksi yang dilakukan pada siklus II ini dapat disimpulkan;

1. Kemampuan siswa dalam proses pembelajaran dengan metode eksperimen sains sudah meningkat. Hal tergambar dalam; (a) Siswa mampu melakukan demonstrasi teks prosedur dengan baik, (b) Siswa mampu mempresentasikan hasil kerja dengan baik, hal ini terlihat dari data observasi yang diperoleh.

2. Meningkatnya minat siswa dalam melaksanakan evaluasi terhadap kemampuan siswa menguasai materi pembelajaran. Hal ini dapat dilihat dari hasil evaluasi. Meningkatnya rata-rata ulangan harian I adalah 71,4 dan pada ulangn harian II menjadi 77,3.

\section{Pembahasan}

Adanya peningkatan hasil belajar siswa dari siklus I ke siklus II pada penelitian tindakan kelas ini menunjukkan bahwasannya penggunaan baik model dan metode tertentu dalam pembelajaran akan mempengaruhi hasil belajar siswa. Pemilihan model pembelajaran Demonstrasi dianggap tepat dalam pengembangan pembelajaran pada materi teks Prosedur di kelas IX. Menurut Suryabrata (1989:142), ada beberapa faktor yang mempengaruhi hasil belajar yang bisa digolongkan menjadi tiga, yaitu: Faktor dari dalam, faktor dari luar, dan faktor instrumen. 1) Faktor dari dalam yaitu faktor-faktor yang dapat mempengaruhi belajar yang berasal dari siswa yang sedang belajar. Faktor-faktor ini diantaranya adalah: (a) minat individu merupakan ketertarikan individu terhadap sesuatu. Dengan tingginya minat belajar siswa bisa menyebabkan pembelajaran siswa lebih mudah dan cepat (b) motivasi belajar antara siswa yang berbeda, seperti; cita-cita siswa, kemampuan belajar siswa, kondisi siswa, kondisi lingkungan, unsur-unsur dinamis dalam belajar, dan upaya guru membelajarkan siswa. Faktor dari luar yaitu faktor-faktor yang berasal dari luar siswa yang mempengaruhi proses dan hasil belajar seperti lingkungan sosial. Lingkungan sosial berupa manusia atau sesama manusia, baik manusia itu hadir ataupun tidak langsung hadir. Faktor instrumen yaitu faktor yang berhubungan dengan perangkat pembelajaran seperti kurikulum, struktur program, sarana dan prasarana pembelajaran media pembelajaran, model/metode pembelajaran.

Hasil penelitian ini sejalan dengan pendapat dari Ahmadi (2011:28) bahwa metode pembelajaran berfungsi sebagai cara dalam penyajian (menguraikan, memberi contoh, maupun memberi latihan) tentang isi pelajaran untuk mencapai tujuan tertentu. Metode pembelajaran yang dipilih untuk dikembangkan dalam sebuah pembelajaran hendaknya disesuaikan dengan karakteristik pokok bahasan mata pelajaran tertentu dan juga siswa supaya memperoleh hasil yang diinginkan.

Dari hasil observasi dan hasil tes belajar menunjukkan bahwa terjadi kenaikan hasil belajar yang signifikan pada siswa ketika mereka telah melakukan ekperimen secara langsung dengan hasil nilai tes karena mereka memahami beberapa kosa kata dengan cara menyebut dan mempraktikkannya pada saat eksperimen atau biasa disebut dengan learning by doing sehingga tidak hanya sekedar menghafal text semata namun juga memahami kandungan isi teks.Sesuai dengan pendapat Syaiful Bahri Djamarah dan Aswan Zain (2006: 82) metode eksperimen (percobaan) adalah bentuk penyajian pembelajaran, di mana anak melakukan percobaan dengan mengalami dan membuktikan sendiri sesuatu yang dipelajari. Dalam kegiatan proses belajar mengajar dengan metode percobaan ini, anak diberi kesempatan untuk mengalami sendiri atau melakukan sendiri, mengikuti suatu proses, mengamati suatu objek, menganalisis, membuktikan, dan menarik kesimpulan sendiri mengenai suatu objek, keadaan, atau proses sesuatu. 


\section{KESIMPULAN}

Berdasarkan data, analisis data dan pembahasan dapat disimpulkan bahwa penerapan metode pembelajaran eksperimen sains sederhana dapat meningkatkan hasil belajar siswa pada materi teks Prosedur. Hal ini dapat dilihat dari hasil tes yang diperoleh mulai dari siklus I sampai pada siklus II.

\section{DAFTAR PUSTAKA}

Ahmadi, lif Khoiru, dkk. (2011). Mengembangkan Pembelajaran IPS Terpadu. Jakarta : Prestasi Pustakaraya.

Anitah, S, (2007). Strategi Belajar Mengajar. Jakarta: Penerbitan Universitas Terbuka

Anitah, S. (2009). Teknologi pembelajaran. Surakarta: Learning Resource Center Faculty of Teacher Training and Education UNS.

Djamarah, S.B., \& Zain, A. (2006). Strategi Belajar Mengajar. Jakarta: Rineka Cipta.

Hamid, Soleh, Moh. (2011). Metode Edutainment. Yogyakarta: DIVA Press.

Hardini, Isriani. (2012). Strategi Pembelajaran Terpadu. Yogyakarta: Familia.

Nasrudin, Harun dkk. (2007). Sains Dasar. Surabaya: Unesa University Press

Puger, I Gusti Ngurah. (2004). Belajar Kooperatif. Diktat Perkuliahan Mahasiswa Unipas.

Roestiyah. (2012). Strategi Belajar Mengajar. Cet. II; Jakarta : Rineka Cipta

Sagala, S. (2005). Konsep dan Makna Pembelajaran. Bandung : Alfabeta.

Anitah, Sri, W, dkk. (2007). Strategi Pembelajaran di SD. Jakarta: Universitas Terbuka.

Suryabrata, S. (1989). Proses Belajar Mengajar di Perguruan Tinggi. Yogyakarta : Andi Offset 